Winter 2002

\title{
Isoetes Toximontana (Isoetaceae), a New Quillwort with Green Megaspores from the Northern Cape of South Africa
}

Lytton John Musselman

Old Dominion University, lmusselm@odu.edu

J.P. Roux

Follow this and additional works at: https://digitalcommons.odu.edu/biology_fac_pubs

Part of the Botany Commons, and the Plant Biology Commons

\section{Repository Citation}

Musselman, Lytton John and Roux, J. P., "Isoetes Toximontana (Isoetaceae), a New Quillwort with Green Megaspores from the Northern Cape of South Africa" (2002). Biological Sciences Faculty Publications. 187.

https://digitalcommons.odu.edu/biology_fac_pubs/187

\section{Original Publication Citation}

Musselman, L. J., \& Roux, J. P. (2002). Isoetes toximontana (Isoetaceae), a new quillwort with green megaspores from the northern cape of South Africa. Novon, 12(4), 504-507. doi:10.2307/3393131 


\title{
Isoetes toximontana (Isoetaceae), a New Quillwort with Green Megaspores from the Northern Cape of South Africa
}

\author{
Lytton John Musselman \\ Department of Biological Sciences, Old Dominion University, Norfolk, Virginia 23529-0266,
} U.S.A.lmusselm@odu.edu

\section{J. P. Roux}

Compton Herbarium, National Botanical Institute, Private Bag X7, Claremont 7735, South Africa. Roux@nbict.nbi.ac.za

ABSTRACT. Isoetes toximontana is only the second quillwort reported from the Northern Cape region in South Africa. It occurs in shallow water on the Gifberg. Megaspores are uniformly tuberculate on the proximal surface; their distal surfaces may have occasional rugi along with bullae. They are olive green when dry. Microspores are brown and aculeate. Preliminary field studies suggest that an unexpected diversity of quillworts is found in this region.

Key words: Gifberg, Isoetaceae, Isoetes, Northern Cape Province, Quillwort, South Africa.

Burrows (1990) recorded six species of Isoetes L. from South Africa, with only two from the Cape region (Cape Agulhus to the Namibian border): I. capensis Duthie and I. stellenbossiensis Duthie. Their presence as the only quillworts in the flora is confirmed in a recent comprehensive treatment of the ferns and fern allies of the Cape (Roux, 2000). Our report here of a new species is the first quillwort documented across this large geographical area.

Isoetes toximontana L. J. Musselman \& J. P. Roux, sp. nov. TYPE: South Africa. Northern Cape Province: Gifberg, shallow water along Gifberg Road, $1 \mathrm{~km} \mathrm{~S}$ of Oubergpad, $31^{\circ} 47^{\prime} 09^{\prime \prime} \mathrm{S}, 18^{\circ} 45^{\prime} 71^{\prime \prime} \mathrm{E}$, ca. $22 \mathrm{~km}$ SE of Vanrhynsdorp, 565 m, 20 Sep. 2001, Lytton J. Musselman \& Elizabeth R. Musselman 200135 (holotype, NBG; isotype, MO). Figures 1, 2.

Planta amphibia, emergens. Excaudex trigonus et radicibus simplicibus. Folia usque ad 10, obscure viridia, rigida, spiralia, usque ad $42 \mathrm{~mm}$ longa, apicibus obtusa, in medio longitudinis ca. $0.5 \mathrm{~mm}$ lata, in sectione transversali elliptica, cellulis epidermalibus omnibus processibus tuberculatis ornatis, prope basim folii tantum, cavernulis aeriis quatuor etiam seriebus stomatum ad as parallelis praeditis, littis peripheralibus absentibus. Megasporophylla microsporophyllaque in eadem planta por- tata. Velum absente; parietes sporangii pellucidos. Megasporae paucae (usque ad 36 per sporangium), olivaceae, $275-320 \mu \mathrm{m}$ in diam., in parietibus proximalibus distalibusque, aeque tuberculatae, tuberculis altitudine variantibus, cingulo angusto sub crista aequatoria posito. Microsporae brunneae usque ad $25 \mu \mathrm{m}$ longae, aculeatae stelis remotis.

Plants amphibious, emergent. Rootstock threesided. Roots simple. Leaves 3 to 10 per plant, dull green, stiff, spirally arranged, up to $42 \mathrm{~mm}$ long, obtuse, ca. $0.5 \mathrm{~mm}$ wide at mid length, elliptic in cross section. Leaf epidermal cells with tuberculate outgrowths, with four air chambers near the base, but these absent toward the leaf apex, with four rows of stomata parallel to the air chambers, peripheral strands lacking. Scales present. Megasporophylls and microsporophylls on the same plant. Velum absent. Sporangium wall clear. Megaspores few (up to 36 per sporangium), gray-green in color, 275-320 $\mu \mathrm{m}$ diam., uniformly tuberculate on the proximal surface, the distal surface with occasional rugi. Tubercules of varying heights, with a narrow girdle below the equatorial flange. Microspores brown en masse, to $25 \mu \mathrm{m}$ long, aculeate with remote stelae. The name is derived from Gifberg, Afrikaans for "poison mountain," where the type was collected.

Spore color, ornamentation, and size. Isoetes toximontana has green megaspores, a character first reported in the genus by Duthie (1929) for I. stellenbossiensis (Fig. 1B, D). It can be distinguished from other Southern African quillworts by megaspore ornamentation and leaf features. Isoetes stellenbossiensis has reticulate megaspore ornamentation; I. capensis megaspores are boldly rugate on the distal surface. (Terminology for spore ornamentation follows Lellinger \& Taylor, 1997.) Based on the figures in Burrows (1990), there are four quillworts in southern Africa with tuberculate mega-

Novon 12: 504-507. 2002. 


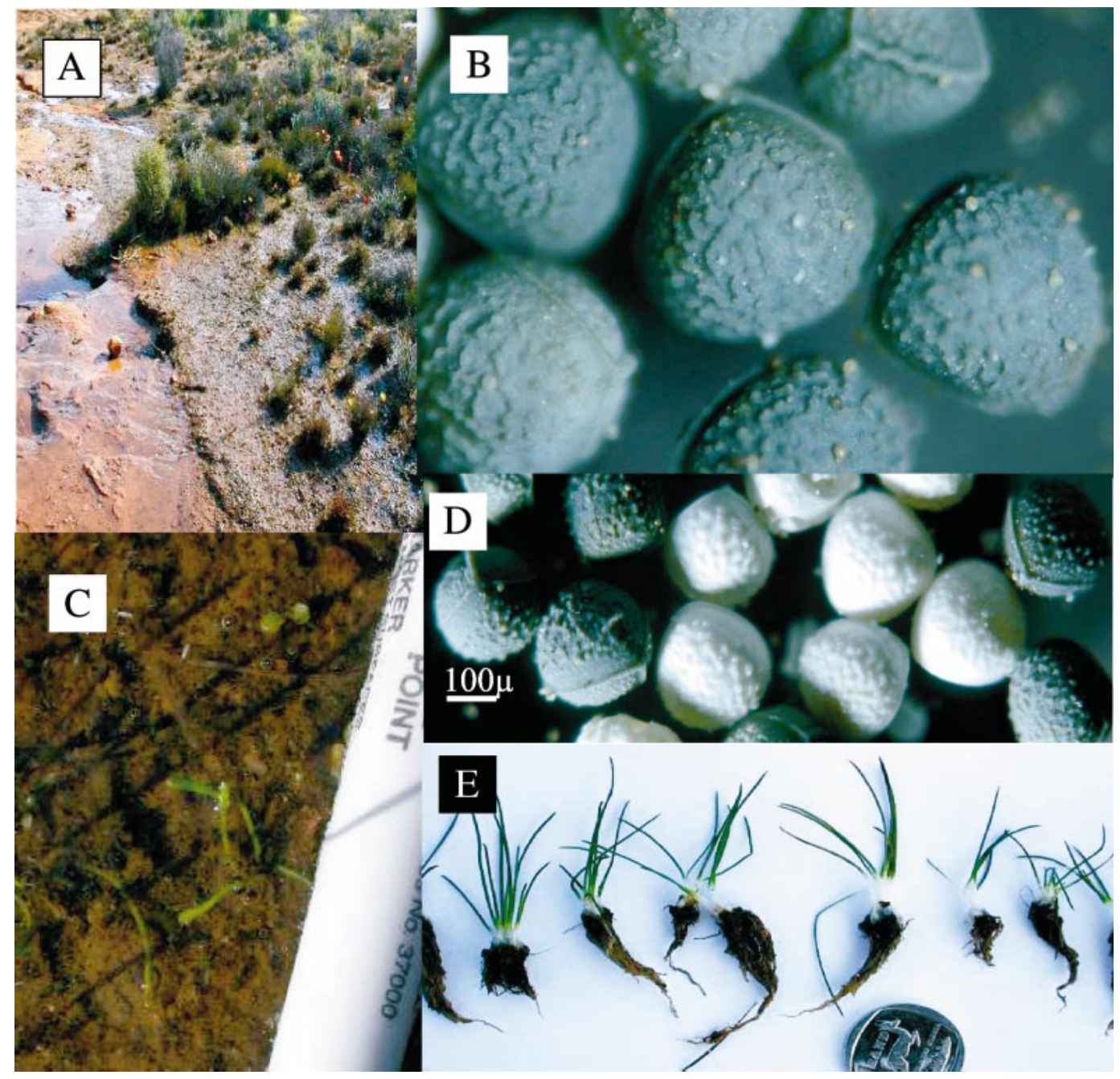

Figure 1A-E. - A. Roadside ditch with shrubby restio. Type location. -B. Megaspores. Brown microspores are evident on the surface. - C. Isoetes toximontana. Note the size of the plants. -D. Mixture of megaspores of I. toximontana (green) and Musselman \& Musselman 2001-33 (white). - E. Representative plants of I. toximontana. The coin is ca. $2 \mathrm{~cm}$ in diameter.

spores: I. giessi Launert, I. transvaalensis Jermy \& Schelpe, I. welwitschii A. Braun ex Kuhn, and I. alstonii Reed \& Verdcourt. Of these, only I. giessi and I. welwitschii lack a velum. Isoetes welwitschii is more tropical in its distribution and in South Africa is known from only a few collections in the eastern part of the country (Burrows, 1990). Quillworts of Namibia are poorly understood, including the taxon known as I. giessi from central Namibia, which does have tuberculate megaspores. However, ornamentation is sparse and megaspores are white. The size of megaspores and microspores of I. toximontana is similar to that of I. stellenbossiensis and I. capensis, both diploids (R. D. Bray, unpublished), suggesting that I. toximontana is also diploid. Mi- crospores are brown (Fig. 1B) and have aculeate macro ornamentation (Fig. 2C). Megasporophylls and microsporophylls were found in mid September on the same plant.

Leaves. Unlike I. stellenbossiensis, the Gifberg quillwort has stomata in rows on the adaxial surface (Fig. 2B, F, G). Leaf epidermal cells have a distinctive ornamentation consisting of knobby outgrowths (Fig. 2F, G). No peripheral strands (collenchyma-like cells) were found (Fig. 2D).

Rootstock and roots. The rootstock is three-sided (Fig. 2H). No branched roots, characteristic of most Isoetes species, were evident in I. toximontana. 


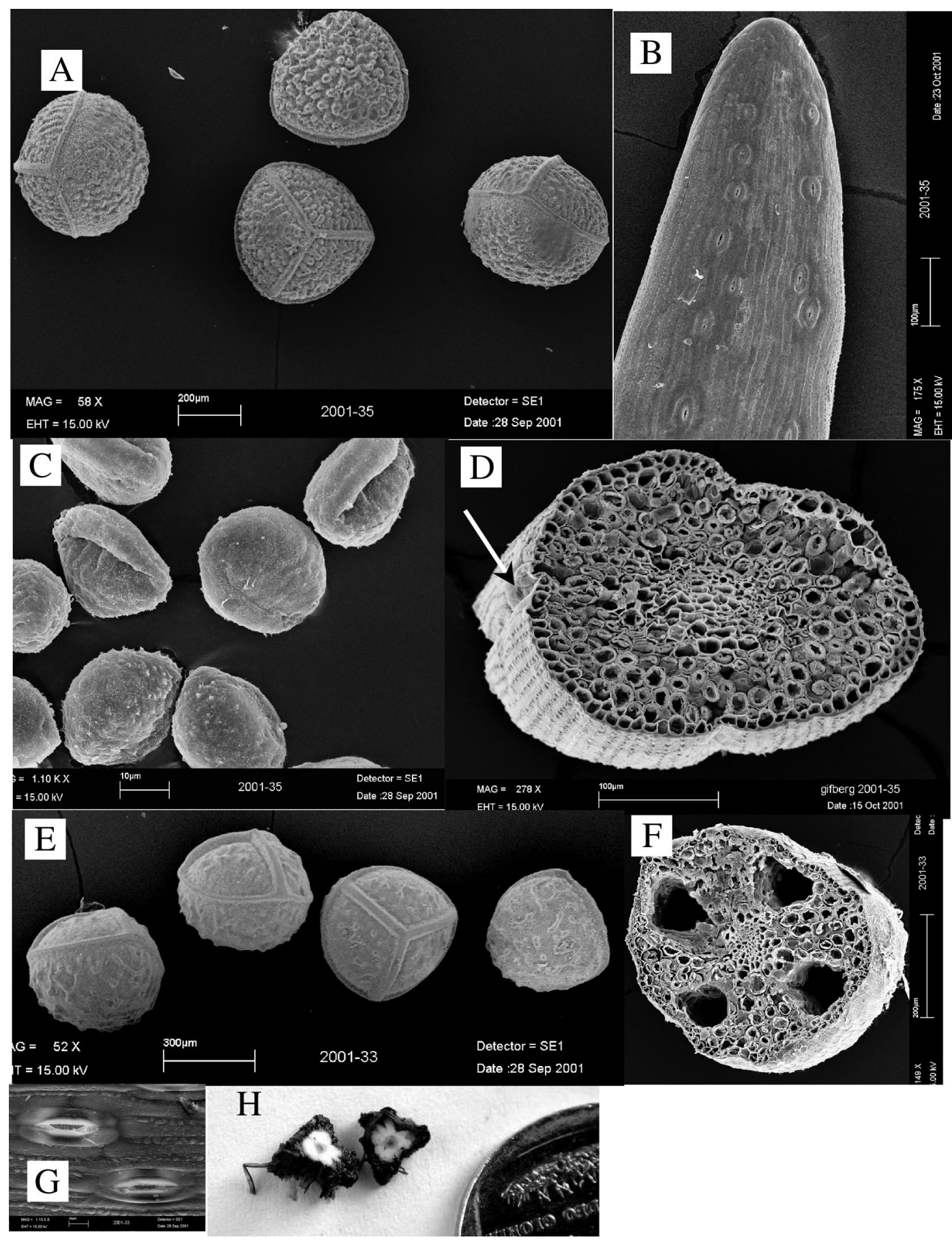

Figure 2A-G. Isoetes toximontana. - A. SEM of megaspores. Scale $=200 \mu \mathrm{m}$. -B. SEM of leaf tip. Note the rows of stomata on the adaxial side. Scale $=100 \mu \mathrm{m}$. - C. SEM of microspores. Scale $=10 \mu \mathrm{m}$. - D. SEM of cross section of leaf at midpoint. Arrow indicates stomatal apparatus. Scale $=200 \mu \mathrm{m} .-\mathrm{E}$. Megaspores of Musselman \& Musselman 2001-33 with rugulate ornamentation. - F. Cross section of leaf of Musselman \& Musselman 2001-33. Note the four air chambers. - G. Two stomata of I. toximontana. - H. Cross sections of rootstocks of I. toximontana. 
Habitat. This diminutive species (Fig. 1C, E) was found only as a submergent in a temporary pond dominated by a semi-shrubby restio (Restionaceae) (Fig. 1A). Our preliminary fieldwork in the Gifberg, the southwestern-most escarpment of sandstone of the Cape System, indicates that several taxa of quillworts may be present. One of these quillworts has white megaspores with rugate ornamentation (Fig. 1D, 2E). At least one putative hybrid was found, distinguished by aborted spores, another indication of the diversity of Isoetes taxa previously unknown in this part of southern Africa.

Preliminary molecular work using ITS sequences indicates that I. toximontana is a distinct species with nine unique substitutions located in a clade with I. capensis (W. C. Taylor, pers. comm.).

Acknowledgments. We thank Denise Wadsworth for preparing materials for scanning electron mi- croscopy and Alan Savitzky for light microscopy. Discussions with Carl Taylor were helpful and encouraging. We thank him for sharing preliminary data from his phylogenetic work on South African quillworts. Research was supported in part by the Mary Payne Hogan fund.

Literature Cited

Burrows, J. E. 1990. Southern African Ferns and Fern Allies. Frandsen Publishers, Sandton.

Duthie, A. V. 1929. The species of Isoetes found in the Union of South Africa. Trans. Roy. Soc. S. Afr. 17: 321330.

Lellinger, D. B. \& W. C. Taylor. 1997. A classification of spore ornamentation in the Pteridophyta. Pp. 33-42 in R. J. Johns (editor), Holttum Memorial Volume. Royal Botanic Gardens, Kew.

Roux, J. P. 2000. Pteridophytes. Ferns and Fern Allies. Pp. 37-50 in P. Goldblatt \& J. Manning, Cape Plants. A Conspectus of the Cape Flora of South Africa. Strelitzia 9: 1-743. 